\title{
How does nutrition influence luteal function and early embryo survival
}

\author{
Pieter Langendijk ${ }^{1}$ and Olli Peltoniemi ${ }^{2}$
}

${ }^{1}$ South Australian Research and Development Institute, South Australia; ${ }^{2}$ Department of Production Animal Medicine, Faculty of Veterinary Medicine, University of Helsinki, Finland

The pre-ovulatory LH surge triggers luteinisation of follicle tissue, but subsequent development of corpora lutea to full size is independent of $\mathrm{LH}$ up to around day 12 of pregnancy. Thereafter, severe (pharmacological) inhibition of LH secretion for 3 to 5 days will result in luteal failure and loss of pregnancy. It is unlikely that nutritional circumstances will have a similar effect, although scenarios with severe undernutrition have hardly been studied during early pregnancy. Milder levels of pre- and postmating undernutrition (around maintenance requirements), do affect luteal tissue development, but whether this is related to variation in $\mathrm{LH}$ is not clear as studies are equivocal, and there are indications that other nutrition related factors, like IGF-1 and insulin, may mediate these effects. A high plane of nutrition seems to increase progesterone secretion by the ovaries, even though systemic progesterone is reduced at the same time. Since there is direct transfer of progesterone from ovarian veins to the uterus, this may explain why a high plane of nutrition may actually benefit embryo survival and pregnancy, although very early during luteal formation (first days after mating), secretion by the ovaries may be overridden by systemic clearance of progesterone on a high feed level. Direct measurement of progesterone secretion by the ovaries is poorly understood as is the transfer of progesterone to the uterus and effects of specific nutrition related mediators such as IGF-1 and insulin on these processes.

\section{Introduction}

After rupture of the pre-ovulatory follicles at ovulation, reformation and reorganization of tissue take place at a remarkable speed, ultimately resulting in the formation of fully functioning corpora lutea by 7-10 d after ovulation, and in sheep, the proliferation rate of different cells involved in luteal tissue formation (luteal cells, endothelial cells, fibroblasts) has been likened to that of rapidly growing tumors (Niswender et al., 2000). The pre-ovulatory LH surge triggers the cascade of luteinising processes but as will be discussed in this paper, other factors control the development and later on, the function of established corpora lutea. Angiogenic factors such as VEGF influence corpus luteum formation and function early on (Schams and Berisha, 2004). Factors other than angiogenic factors that have been described are cytokines in cattle (Webb et al. 2002), luteotrophic factors like LH (see below), and IGF-1 (Ptak et al., 2003, 2004; Miller et al., 2003; Schams et al., 1999). The importance of some factors in the development 
and function of established luteal tissue in the pig will be discussed, only where there is an identified relation to nutrition, based on the available literature.

Figure 1 shows the development of luteal tissue and a typical profile of systemic progesterone during the embryonic phase. From figure 1 it can be deducted that porcine corpora lutea reach their full size between day 10 and 12 after ovulation, with total luteal mass at this stage ranging between 6 to $8 \mathrm{~g}$ in gilts and 10 to $15 \mathrm{~g}$ in multiparous sows (Langendijk 2012, unpublished results). A major factor determining total luteal mass is ovulation rate, with the correlation between ovulation rate and luteal mass ranging between 0.45 and 0.62 (Almeida et al., 2001; Willis et al., 2003; Athorn et al., 2012). This explains why multiparous sows have more luteal tissue than gilts and first parity sows. Systemic concentration of progesterone is related to total luteal mass $(r=0.26-0.45$; Athorn et al, 2012), although this relationship is probably underestimated because it is generally based on blood samples obtained at a different time point than the assessment of luteal mass. Reflecting this relationship, progesterone in the circulation roughly follows the development in luteal tissue mass. After day 12-13 the luteal tissue mass decreases again but the reason for this is unknown.

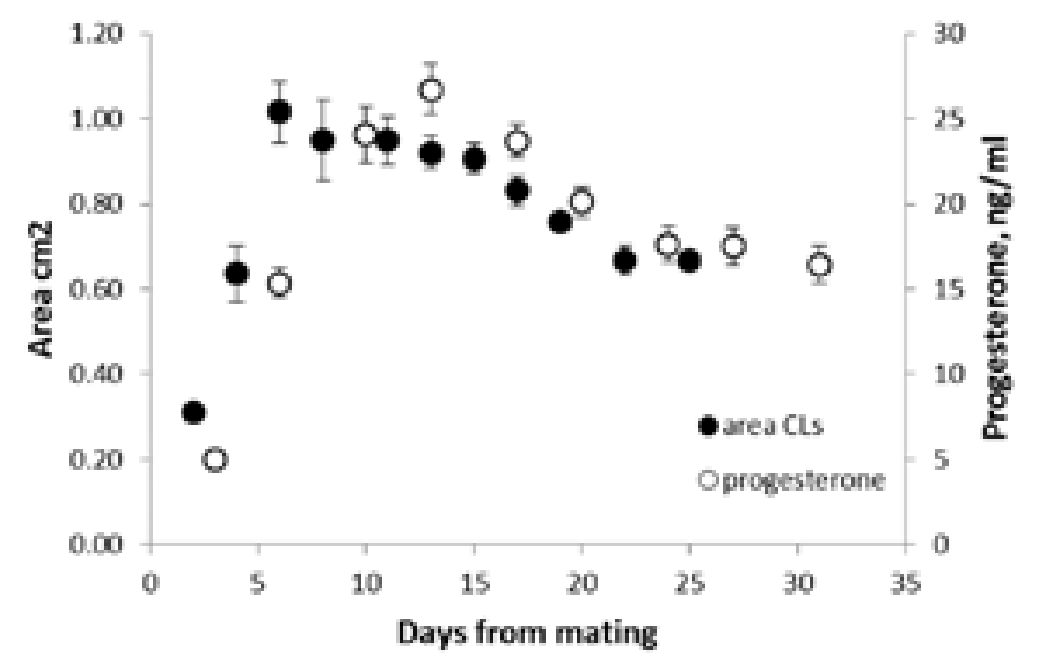

Fig. 1 Development of luteal tissue (average area of CLs measured using ultrasound) in 6 sows and gilts during early gestation (closed circles), and systemic progesterone measured in a different group of sows (open circles). Data from Tast et al. (2002) and from Bouwman et al. (2012, unpublished)

\section{Role of LH in establishing and maintaining luteal tissue}

In pigs, development of the corpora lutea after ovulation and the secretion of progesterone occur independent of LH input from the pituitary, at least until 10-12 days after ovulation (Peltoniemi et al., 1995). Hypophysectomy on the day after oestrus or mating does not prevent the development of normal-sized, progesterone-secreting corpora lutea by day 12 after oestrus (Anderson et al., 1967), but corpora lutea do regress between days 16 and 20 in pregnant, hypophysectomised sows. Meduri et al. (1996) showed that at $48 \mathrm{~h}$ after follicle rupture, there is a marked decrease in the density of LH receptors in luteal cells, and 6 days after ovulation the receptor density seems to increase again. These findings indicate an $\mathrm{LH}$-independent and $\mathrm{LH}$-insensitive window during early development of the corpus luteum. 
More recent studies by the group of Peltoniemi et al. have approached the role of LH in the maintenance of luteal tissue using three different models. First, pregnant gilts received GnRH agonist implants to down regulate $\mathrm{GnRH}$ receptors and suppress LH pulsatility (Peltoniemi et al., 1995). Second, active and passive immunisation against $\mathrm{GnRH}$ was used to reduce $\mathrm{LH}$ pulsatility in the early pregnant gilt (Tast et al., 2000). Third, a GnRH antagonist was used to directly down regulate LH pulses (Virolainen, 2003).

Based on these models, beyond days 10 and 12 of pregnancy, support of the corpora lutea by LH does become important, although in some studies it seems that reduction in gonadotrophic support has to be severe and chronic to result in luteal regression and pregnancy failure. $\mathrm{LH}$ secretion during the luteal phase of the oestrous cycle and during early pregnancy is characterised by a lesser frequency of greater amplitude LH pulses (Langendijk et al., 2007 and figure 2). Chronic treatment with a GnRH agonist from days 14 to 21 of pregnancy abolished LH secretion and resulted in a decrease in progesterone secretion and loss of pregnancy in all sows at around 15 days after the start of treatment (Peltoniemi et al., 1995). Similarly, Easton et al. (1993) observed a decline in progesterone between 13 and 21 days after implantation with a slow-release agonist of GnRH (at oestrus), which is $3 \mathrm{~d}$ to $11 \mathrm{~d}$ after corpora lutea have started to become sensitive to $\mathrm{LH}$. The use of a GnRH agonist by its nature initially increases LH release before down-regulating LH pulses, and may also cause some extra luteal tissue to be formed, delaying the suppression of $\mathrm{LH}$ and effects on luteal function. In contrast, single injection with a GnRH antagonist between days 14 and 19 after ovulation resulted in a more immediate disruption of LH secretion for a period of 2.7 days, on average, and loss of pregnancy in three of 15 sows (Virolainen et al., 2003). Active or passive immunisation against GnRH (Tast et al., 2000) also had a more immediate effect with a reduction in progesterone within 2 to 4 days, and luteal failure evident within 7-10 days from immunization. In the immunisation model none of the sows maintained pregnancy. Interestingly, immunization at day 10 of pregnancy seemed to cause a reduction in progesterone and failure to establish pregnancy before total luteal failure occurred, whereas immunization at day 20 of pregnancy resulted in total luteal failure before abortion occurred. The first observation may provide some explanation for seasonally related pregnancy failure.

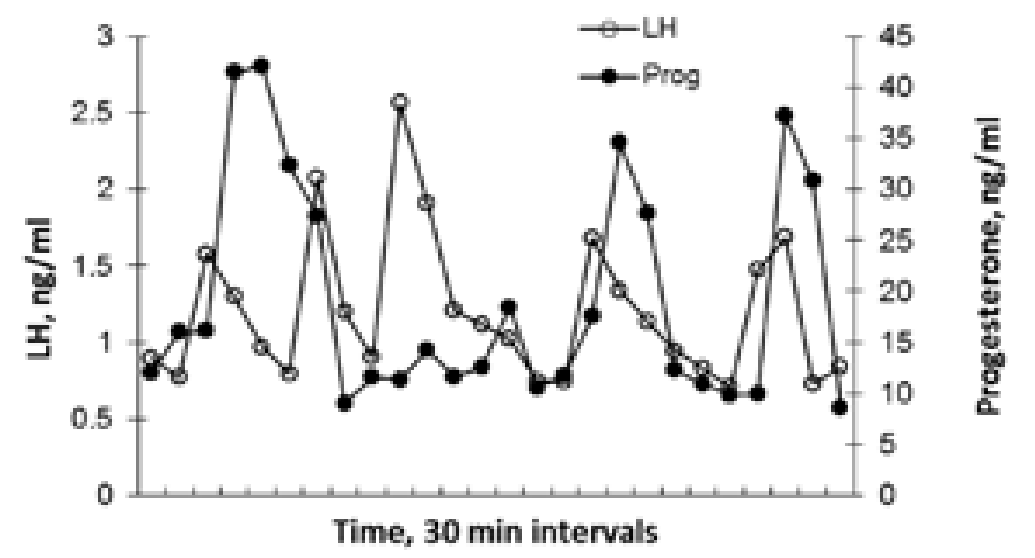

Fig. 2 Pulsatile profile of progesterone in the caudal vena cava (closed circles), and LH (open circles) for an individual gilt during a $12 \mathrm{~h}$ sampling period at day 22 of pregnancy. Data from Virolainen et al. (2005).

The models described above indicate that a strong suppression of $\mathrm{LH}$ that lasts 3 to 5 days will result in luteal failure and as a consequence result in no pregnancy being established or 
abortion, depending on the stage of pregnancy. This is supported by recent data from $\mathrm{O}^{\prime}$ Leary et al. (2012, personal communications), who treated gilts with $40 \mathrm{mg}$ of altrenogest daily from day 14 through day 24 of pregnancy, and reported an immediate regression of luteal tissue (determined by ultrasound) and a drop in progesterone to basal levels by day 18, in 4 out of 5 gilts. The gilts aborted when altrenogest treatment ceased. As a conclusion, there is enough evidence to state that $\mathrm{LH}$ secretion or a minimum of $\mathrm{LH}$ pulses is important to support CL and maintenance of early pregnancy in the pig, beyond day 12 after fertilisation.

It is less clear how physiological variation in LH secretion directly affects progesterone secretion. Progesterone is secreted by the ovaries in pulses, which only becomes clear when blood is sampled frequently from the caudal vena cava. However, only some of these pulses are temporally associated with LH pulses (Virolainen et al. 2005; Brüssow et al., 2011). One could speculate that a low level of LH secretion is sufficient for the function of corpora lutea in terms of progesterone secretion. In fact, Easton et al. (1993) suggested that a few pulses of $\mathrm{LH}$, rather than a certain basal level of $\mathrm{LH}$, are important for luteal function. If so, variation in LH secretion within a physiological range, as observed in some reports (Prunier et al., 1993; Peltoniemi et al., 1997a; Peltoniemi et al., 1997b), would not have much influence on luteal maintenance. Nevertheless, progesterone concentration is transiently elevated once LH secretion is stimulated pharmacologically by a GnRH agonist (Peltoniemi et al., 1995), and treatment with eCG at day 10 of gestation had an immediate effect on progesterone ( $\mathrm{O}^{\prime}$ Leary et al., 2011). Even though normal variation in $\mathrm{LH}$ secretion during the luteal phase may not have a direct effect on progesterone concentration, LH secretion may be important for luteal function in the long term. It has been shown that $\mathrm{LH}$ affects the number of luteal cells and treatment of sheep with hCG in the early luteal phase causes a shift in the size distribution of luteal cells, from small to large luteal cells (Fitz et al. 1982). Therefore, differences in LH secretion may affect progesterone secretion in the long term due to differences in steroidogenic properties of small and large luteal cells (Fitz et al. 1982; Niswender et al. 1985). These differences may be reflected by changes in total luteal mass, as shown by Quesnel et al. (2000) in cyclic gilts treated with an LH antagonist that diminished LH pulses in the luteal phase.

\section{Pre mating nutrition}

The effects of pre-mating nutrition on luteal function after ovulation have not been studied as such. However, there is an abundance of studies designed to explore the effects on follicle development and ovulation rate. Some of these studies report on carry-over effects on postmating luteal function. These studies have mainly focused on the effects of feed level during the follicular phase, or earlier, during the luteal phase of the preceding cycle in gilts, and lactation in primiparous sows. Feed restriction (maintenance vs 2.5-3.5 kg) during the second week of the luteal phase in gilts for example, resulted in a slower rise in progesterone after subsequent ovulation (Almeida et al., 2001; Chen et al., 2012a). Administration of insulin counteracted this effect in vivo (Almeida et al., 2001) and resulted in increased progesterone secretion in vitro (Mao et al., 2001). Ashworth et al. (1999) also reported increased progesterone in gilts fed a high feed level (3.5 kg vs $1.15 \mathrm{~kg}$ ) pre-mating, and reported an increase in the weight of corpora lutea. In primiparous sow models, feed restriction during late lactation had similar carry-over effects on post-ovulatory luteal function with progesterone being lower in feed restricted sows (Mao et al., 1999). Van den Brand et al. (2001) compared a fat rich and starch rich diet post weaning and reported higher insulin levels but a lower luteal tissue mass (at d35 of gestation) in sows on the starch diet $(6.2 \mathrm{~g}$ vs $7.0 \mathrm{~g})$, however, progesterone was not measured. Chen et al. (2012b), on the other hand, fed a starch/sugar rich supplement during late lactation and reported 
higher progesterone at $\mathrm{d} 4$ after ovulation compared to control sows and sows fed a fat-rich supplement. In multiparous sows post-weaning insulin characteristics were positively related to post-ovulatory progesterone. This was even though sows on a diet designed to increase insulin did not have a higher progesterone, and even had less luteal mass (9.7 g vs $11.2 \mathrm{~g}$ ) at d10 after ovulation (Wientjes et al., 2011). It seems that pre-mating nutritional treatments (specifically feed level), that improve follicle function and development in general, have positive carry-over effects on post-ovulatory secretion of progesterone. This may be a remnant effect on number or quality of follicle cells, that may influence their secretory capacity after luteinisation, and the effect may be mediated by factors related to metabolic condition such as IGF-1 and insulin. However, the mechanism in terms of development of luteal tissue mass or secretory capacity of that tissue, is not yet clear.

\section{Post mating nutrition}

Post mating effects of nutrition on luteal function have to be separated in those that influence formation and establishment of luteal tissue mass and secretory capacity, and direct effects on secretory function. A number of studies report an increase in luteal tissue mass in gilts fed a high feed level compared to those fed around maintenance during the first 2-3 weeks after ovulation. In gilts fed 2.4 M vs 1.2 M during the first $25 \mathrm{~d}$ of pregnancy (Athorn et al., 2012), luteal weight at $\mathrm{d} 35$ of gestation was increased ( $7.2 \mathrm{vs} 6.7 \mathrm{~g}$ ). In multiparous sows that ovulated during lactation on a reduced suckling regime a $2.5 \mathrm{~kg}$ feed reduction during the first week of pregnancy resulted in reduced luteal tissue mass ( $7.7 \mathrm{vs} 9.5 \mathrm{~g}$ ) at d30 of gestation (Gerritsen et al., 2008). These reports assessed luteal tissue mass late after treatments, and short term effects have not been reported much although Athorn et al. (2012b) found a lower luteal tissue mass in feed restricted gilts (7.9 vs $8.2 \mathrm{~g}$ ) at $\mathrm{d} 10$ of gestation (n.s.). Partial replacement of cereals in the early pregnancy diet by a fat source did not alter total luteal tissue mass (Athorn et al., 2012).

The indirect effects of feed level on luteal tissue formation may be mediated by $\mathrm{LH}$, since complete blocking of LH pulses (but basal LH unaffected) with a $\mathrm{GnRH}$ antagonist (Antarelix) in the luteal phase of cyclic gilts reduced the weight of corpora lutea and systemic progesterone (Quesnel et al., 2000). However, effects of feed level on LH are equivocal. The effect of undernutrition on secretion of gonadotrophins has mostly been studied in prepubertal gilts, mature cyclic gilts, or lactating sows. Moderate feed restriction (fed to maintenance) for at least a week will reduce LH secretion in prepubertal and cyclic gilt models (Booth et al., 1990; Booth et al., 1996), and severe feed restriction (under maintenance) has been reported to have the same effect on the long term (Armstrong and Britt, 1987). Acute feed deprivation for a short period (one or two days), however, does not necessarily affect LH secretion within $24 \mathrm{~h}$ in mature and prepubertal gilts (Barb et al., 1997; Barb et al., 2001). During the luteal phase in cyclic gilts or during early pregnancy, when LH secretion is limited by negative feedback from progesterone anyway, effects of feed restriction (close to maintenance requirement) have not been studied as much and the available results are equivocal. Some studies report no effect of moderate feed restriction on LH during the luteal phase or early pregnancy (Quesnel et al., 2000, Peltoniemi et al., 1997a, only amplitude of LH pulses). In contrast, some studies have reported a reduction in LH secretion in feed restricted pregnant gilts (Ferguson et al., 2003; Peltoniemi et al., 1997b). These studies did not report on luteal tissue mass, except for Quesnel et al (2000), who observed no effect of feed restriction on LH or luteal tissue mass. Therefore it is hard to establish whether the reported effects of feed level on LH, which are mild compared to the studies presented earlier with exogenous manipulation of $\mathrm{LH}$, do have a biologically significant impact on luteal tissue formation. This paradigm is poorly established 
and requires more research on the effect of moderate and severe feed restriction on LH, IG-1, and insulin, luteal tissue mass, and progesterone secretion, during the windows when luteal tissue is "independent" of $\mathrm{LH}$ and thereafter.

Direct effects of nutrition on secretory function of luteal tissue may be mediated by IGF-1 and insulin, since these have been reported to be higher in gilts fed a high feed level during early pregnancy (Ferguson et al., 2003; Novak et al., 2002). However, no clear relationship in these studies was established. Bovine (Einspanier et al., 1990) and porcine (Ptak et al., 2003) luteal cells, for example, produce more progesterone when stimulated with IGF-1 in vitro, and Ptak et al (2004) reported reduced apoptosis in luteal cells treated with IGF-1 in vitro. Especially during the early luteal phase bovine luteal tissue contains increased numbers of IGF-1 receptors (Schams et al. 1999). The influence of IGF-1 on luteal function in the pig has not only been established in vitro, but also in vivo by Miller et al. (2003), who found an acute increase in progesterone production when IGF-1 was infused in the ovarian vasculature. Langendijk et al. (2008) reported an in vivo relationship between IGF-1 and progesterone shortly after ovulation in primiparous sows. Despite these relationships, there have hardly been any studies that aimed to use dietary manipulations to alter IGF-1 level and luteal function. An increase in feed allocation generally increases IGF-1 in the circulation (Barb et al., 2001; Ferguson et al., 2003). Nevertheless, Novak et al. (2003) did not find a higher progesterone in oviduct veins at $72 \mathrm{~h}$ after ovulation in gilts on a high post mating feed level. However, these samples were taken under general anaesthesia, which may have affected the progesterone values. Samples taken from the caudal vena cava close to where the utero-ovarian veins drain, showed an increase in the number of progesterone pulses and in mean progesterone in gilts fed a high feed level (Athorn et al., 2012b). Manipulation of feed ingredients (starch or sugars replacing fat) has only marginal effects (Wientjes et al., 2011) on IGF-1. In this respect it is interesting to note that in gilts on a high feed level, replacement of starch in the diet with a fat source increased progesterone secretion (at d15 of pregnancy), whilst luteal tissue mass (at d35) seemed to be unaltered (Athorn et al., 2012a). No difference in IGF-1 was reported between these diets. More work is required with models that manipulate insulin, IGF-1, fats in the diet, and other potential modulators of luteal function like PGE2.

The role of $\mathrm{LH}$ in mediating direct effects of nutrition on luteal function is not clear. As mentioned, blockage of LH with Antarelix resulted in less luteal mass and lower systemic progesterone but this may also be a long term effect (Quesnel et al., 2000). In the same study, feed restriction did not affect LH or progesterone. Ferguson et al. (2003), however, reported a decrease in $\mathrm{LH}$ in feed restricted gilts, but an increase in systemic progesterone. The effects of a $\mathrm{GnRH}$ antagonist on progesterone secretion during the luteal phase of cyclic gilts does indicate that, although during this window corpora lutea are independent of LH, they are still sensitive to $\mathrm{LH}$, unless other mediators of feed restriction are involved. At day 6 and day 10 after ovulation, feed restriction close to maintenance level, from mating onwards, does reduce progesterone secretion by the ovaries, based on measurements in the caudal vena cava (Athorn et al., 2012b). This reduction in progesterone appears to be independent from LH, since only chronic feed restriction for months (Prunier et al., 1993), and not short term restriction during the luteal phase (Quesnel et al., 2000) affected LH secretion.

As pointed out above, moderate feed restriction has equivocal effects on $\mathrm{LH}$ and unfortunately some of the studies mentioned did not assess progesterone. There is some indication for a direct stimulatory effect of gonadotrophins in studies with GnRH agonists (Peltoniemi et al., 1995) or hCG (O'Leary et al., 2011). However these studies do not reflect the magnitude of impact nutritional manipulations have on LH. More extreme nutritional manipulations such as fasting have rarely been studied. Razdan et al. (2004) reported an increased systemic progesterone 
during a 2-d fasting period (d13-14 of gestation), whereas Langendijk et al. (2012, unpublished data), observed a drop in systemic progesterone in gilts in the days following fasting on day 10 and 11 of gestation, as well as a smaller litter size at farrowing. The increase in progesterone during fasting was thought to be originating from the adrenal glands as part of an acute stress response to the feed deprivation (Razdan et al. 2004) but will to some extent have been a consequence of reduced clearance by the liver. The reduction in progesterone after fasting is probably not a consequence of altered $\mathrm{LH}$ secretion, since $\mathrm{LH}$ secretion (in prepubertal gilts) does not seem to be affected by a two day fast (Barb et al., 2001) .

The group of Peltoniemi et al. have examined the effects of feeding strategies on $\mathrm{LH}$ secretion during early pregnancy in the gilt and sow (Virolainen et al., 2004; Virolainen et al., 2005b). Three feeding regimens from mating through day 34 of pregnancy, high, low and modified (low until day 14, high until day 21 and low thereafter), were applied to explore effects of feeding on LH secretion and fertility. Modified feeding, which was thought to combine the benefits of restricted feeding after ovulation and abundant feeding during implantation, were first tested on three groups of eight gilts in autumn. The pregnancy rate was higher in the high group (100\%) than in the low $(25 \%)$ or modified (38\%) groups, although the high group had significantly lower systemic progesterone concentrations on days 9 and 12. The basal and mean LH levels were higher in the high group than in the modified group. The $\mathrm{LH}$ amplitude tended to be higher for gilts in the high group. The modified feeding strategy failed to provide the benefits anticipated. Instead, the high feeding strategy provided a distinct advantage in pregnancy rate.

The same regimens were tested during early pregnancy in the multiparous sow (Virolainen et al., 2005b). In this experiment, dietary treatment did not significantly affect LH characteristics (mean, pulse amplitude, pulse frequency and basal level). However, systemic progesterone concentration tended to be lower in the high group than in the low group. In the modified group, progesterone concentration seemed to be associated with the level of feeding. Neither high feeding nor modified feeding provided any benefits for reproductive performance in multiparous sows.

In summary, effects of normal range feed levels on LH and progesterone secretion (not systemic concentration) seem mild, with a higher plane of nutrition increasing progesterone secretion and positively affecting embryo survival and the maintenance of pregnancy. Extreme variations in feed level such as temporary fasting or feed incidents may have more profound effects but have hardly been investigated. Especially effects of (longer term) extreme variations in feed intake on luteal failure are of interest, but also effects of short term variations on progesterone variation prior to implantation. There are also indications for mild effects of other nutritional manipulations on progesterone secretion, such as increasing dietary fat content and ingredients that stimulate IGF-1. Increased feed level does seem to increase luteal tissue mass which may represent more indirect effects of even mild nutritional manipulations on progesterone secretion.

Even though variation in feed intake may only mildly affect $\mathrm{LH}$ and progesterone, there are some indications that during periods of seasonal infertility, these effects may be involved in pregnancy failure. Some reported data suggest there are seasonal effects on progesterone supply towards the uterus (Virolainen et al., 2005a). It has been proposed that $\mathrm{LH}$ secretion may be weak under long days combined with restricted feeding during implantation, resulting in decreased progesterone secretion by the ovaries, and affecting oestradiol signalling by the embryos around day 17 of pregnancy, causing interruption of pregnancy and return to oestrus between d 25-35, typical for seasonal infertility (Tast et al., 2002). In contrast, short days in combination with high plane feeding stimulated pineal gland secretion of melatonin and LH from the pituitary; and maintained pregnancy (Peltoniemi and Virolainen, 2006). These 
observations are supported by the beneficial effects of abundant feeding on pregnancy rates in gilts (Virolainen et al., 2004) and sows (Virolainen et al., 2005a).

\section{Local vs systemic progesterone}

Effects of nutrition on progesterone secretion are complicated by the metabolisation and clearance of progesterone from the systemic circulation by the liver. The liver is the primary organ responsible for clearance of progesterone, and the metabolisation rate increases with feeding level (Prime and Symonds, 1993).

It is important to note that supply of progesterone to the uterine horns does not only rely on systemic progesterone. There is also transfer of progesterone through a counter-current transfer and through lymphatic pathways, and anastomoses between ovarian veins and uterine arteries. These pathways may shunt progesterone directly from ovarian venous blood to arterial blood supplying the oviducts and uterine horns (Krzymowski et al. 1990). As this local supply of progesterone is direct, it is not subject to hepatic metabolism like that of systemic progesterone. Therefore an increase in feeding hypothetically increases progesterone secretion by the ovaries and supply to the uterus, whereas clearance from the systemic circulation is increased at the same time. The net effect of these processes eventually determines the available progesterone. Thus, the influence of a high feeding level on progesterone secretion and luteal function can only be truly assessed when taking into account the transfer at a local level, or at least by measuring progesterone as close to the ovaries as possible, unaltered by systemic clearance.

It is not known to what extent the shunting of progesterone by counter-current transfer and other mechanisms, affects the supply of progesterone to the oviduct and uterus. Pharazyn et al. (1991) reported that progesterone in both ovarian and oviductal venous drainage was higher than systemic but found no difference in progesterone concentrations between uterine venous drainage and the jugular vein up to Day 16 of gestation. This suggests that ovarian progesterone may only have an effect on progesterone supply to the oviduct and that the effects of elevated plasma progesterone are limited to the period in which the embryos are in the oviduct. However, Stefanczyk-Krzymowska et al. (1998) measured progesterone concentrations in blood plasma from branches of the uterine artery supplying both the ovarian and cervical ends of the horn, and found that progesterone was higher in both those arteries compared with the jugular vein. Stefanczyk-Krzymowska et al. (1998) also noted that progesterone concentrations in the uterine artery distal to the ovary were significantly lower than in the uterine artery proximal to the ovary. Pharazyn et al. (1991) may have found no difference in progesterone concentrations in uterine veins because a vast majority of the hormone (20 to $30 \%$ of systemic progesterone) is taken up by uterine tissues (Magness et al., 1986), with less progesterone passing through the uterine veins. In a previous study conducted in our laboratory, ovaries were removed from one uterine horn, whilst leaving the opposite horn intact. Higher embryo numbers were found in the horn that was exposed to both local (i.e. direct ovarian supply) and systemic progesterone, compared with the contralateral horn (6.3 vs 5.0 embryos), which was only exposed to systemic progesterone. This difference was more evident in those animals on a high feeding level (Athorn et al. 2011).

There are a small number of studies that provide some indication of the magnitude and variation in progesterone when measured close to the source (see Figure 2). Athorn et al. (2012 and Virolainen et al. (2005) showed that secretion by the ovaries is extremely pulsatile and the concentration in the utero-ovarian vein is much higher (mean $88 \mathrm{ng} / \mathrm{ml}$ vs $19 \mathrm{ng} / \mathrm{ml}$; Athorn et al., 2012) than in the systemic circulation. The number of pulses, based on the limited data available, does seem to increase with establishment of luteal function (Athorn et al., 2012), from 
7 pulses per $12 \mathrm{~h}$ at day 6 of pregnancy to 10 pulses per $12 \mathrm{~h}$ at day 10 (Athorn et al., 2012), and decrease again to 6 to 8 pulses per $12 \mathrm{~h}$ between day 11 and 17 (Brussow et al., 2011), and 0 to 5 pulses by day 22 (Virolainen et al., 2005). The release of progesterone seems to be a fairly autonomous process, since the progesterone pulses correlate poorly with $\mathrm{LH}$ pulses (Virolainen et al., 2005; Brussow et al., 2011). A high (2.4M vs 1.2M) feed level did have a mild positive effect on progesterone in the vena cava in the early embryonic phase (d6-9; Athorn et al., 2012), but not in established pregnancy (Virolainen et al., 2005, d20-24). Novak et al. (2003) also provide some insight in the magnitude of progesterone in the oviductal and ovarian vein very early after ovulation. Although these authors did not take serial samples to establish time variation, they did show a much higher progesterone in the ovarian vein, and also that a higher post-mating feed level resulted in a higher concentration of progesterone in that vein although this was not significant.

\section{Feed level and embryo survival}

There is no doubt that progesterone is important for remodelling the endometrium to allow successful implantation of, and supply of nutrients to the conceptuses, and hence, systemic progesterone during early gestation (72 $\mathrm{h}$ post ovulation) correlates with embryo survival (Foxcroft, 1997, $r=0.48$; Zak et al., 1998, $r=0.72$ ). Beyond this window embryo survival is not always reported to be correlated to progesterone (Athorn et al., 2012, Gerritsen et al., 2008). Providing greater amounts of feed reduces systemic concentrations of progesterone due to increased hepatic clearance (Prime and Symonds, 1993). Therefore, feeding a high amount of energy is generally believed to reduce embryo survival (Jindal et al., 1996). However, results of studies on nutritional state during early pregnancy are equivocal (e.g. Quesnel et al., 2010). Figure 3 shows a number of studies that compared a range of feed levels. There is a wide variation in the feed levels that have been tested. The lower feed level generally ranges between 1.2 and $2.5 \mathrm{~kg}$, which is still higher than some field recommendations that go as low as maintenance. Clearly, the study by Jindal et al. (1996) showed that a high feed level in the early $3 \mathrm{~d}$-window after ovulation had a negative impact on embryo survival. Two studies that reported a negative effect of a high plane of nutrition during the entire embryonic phase also reported a positive effect of the same high plane on pregnancy rate (Dyck and Strain, 1983; Virolainen et al., 2004). Most other studies, however, do not find a negative effect of a high feed level beyond day 3 on embryo survival, despite a consistent reduction in systemic progesterone, and a number of studies even find a positive effect of a high feed level on embryo survival (e.g. Quesnel et al, 2010; Athorn et al., 2011).

It has to be pointed out that the earlier study by Jindal et al. (1996) focused on the period shortly after ovulation. In later studies, this feed level paradigm has subsequently been translated, and maybe wrongly so, to the entire embryonic period. It also has to be noted that in older studies plane of nutrition is applied during the premating as well as the post-mating period. This has effects on ovulation rate and therefore complicates the separation of post mating effects from effects established earlier on (Foxcroft, 1997).

Embryo survival data obtained during early gestation (up to day 15) have to be interpreted with caution. Efficiency of flushing methods (morulas and blastocysts), and the fragility of embryos and morphological aspects once embryos start to elongate, can complicate the assessment of the number of embryos (Jindal et al., 1997; Ashworth et al, 1999; Athorn et al., 2012a).

The paradox between effects of feed level on systemic progesterone and embryo mortality in some studies may be due to the fact that these studies focused on the relationship between embryo survival and progesterone concentrations in the systemic blood circulation, rather than 

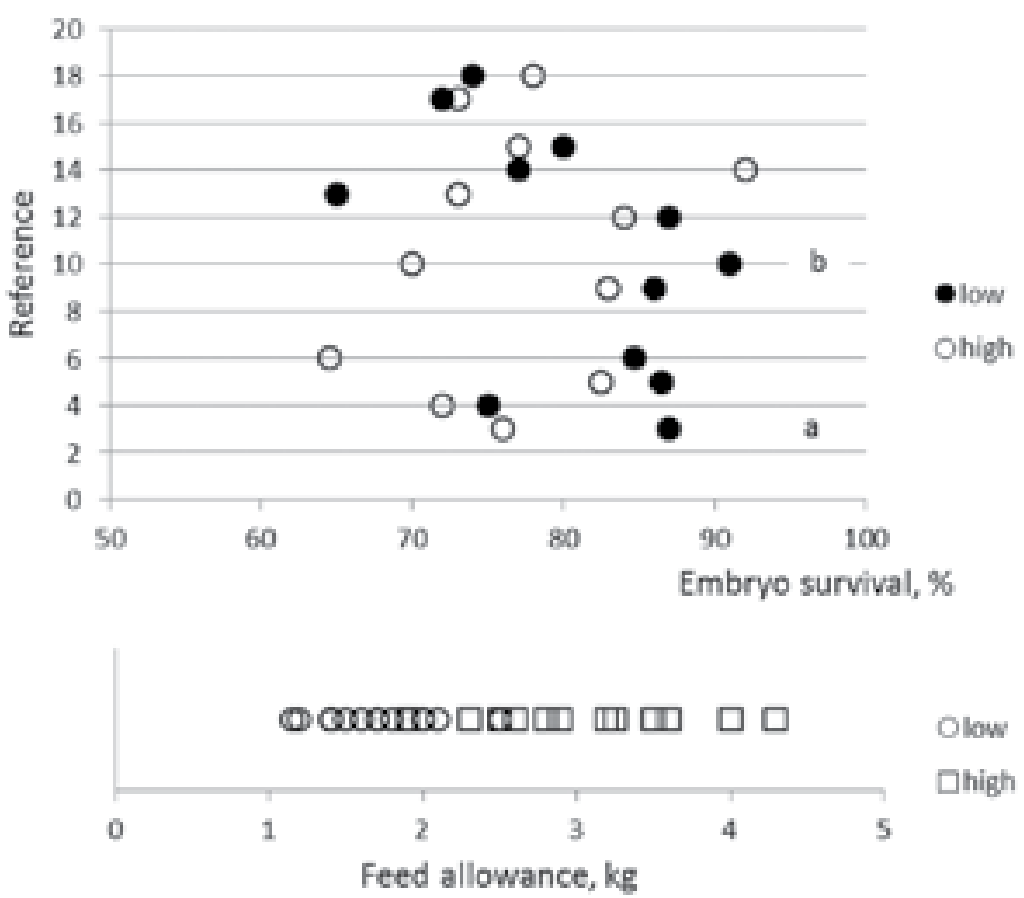

Fig. 3 Feed allowance in different studies with low and high feed level (bottom panel), and embryo survival in gilts (or sows) fed a low or high feed level during early gestation (upper panel). In the upper panel, each number on the $y$-axis represents one reference with one treatment on a high and one treatment on a low feed level. aPregnancy rate for this reference was $64 \%$ on the low and $87 \%$ on the high feed level. bPregnancy rate for this reference was $25 \%$ on the low and $100 \%$ on the high feed level. References: 3 Dyck and Strain (1983) ; 4 Toplis et al. (1983); 5 Pharazyn et al. (1991); 6 Jindal et al. (1996); 9 Ashworth et al. (1999); 10 Virolainen et al. (2004); 12 Virolainen et al. (2005); 13 Quesnel et al. (2010); 13 Athorn et al. (2011); 14 Athorn et al. (2012); 15 Athorn et al. (2012); 17 Hoving et al. (2012); 18 Soede et al. (1999)

concentrations in the blood supply to the uterus. As explained before, the supply to the uterus is not synonymous with systemic supply, because progesterone is 'locally' supplied directly from the ovary to the uterus, via counter current exchange and venous-arterial anastomoses (Krzymowski et al. 1990). Therefore, while a high feed intake decreases systemic concentrations of progesterone, it may actually increase the local supply of progesterone to the uterus via an increase in the secretion of progesterone by the ovaries. The amount of progesterone that is supplied to the uterus, and the effect of feeding level on this supply, will ultimately depend on the balance between the systemic clearance of progesterone and the ovarian production of progesterone.

\section{Dynamics in progesterone secretion}

The confusing effects of feed level on progesterone measurement in the systemic circulation and effects of feed level on embryo survival may be better understood if the dynamics of progesterone secretion throughout the first weeks of pregnancy and the above distinction between systemic and local circulation are taken into account. The secretion of progesterone by the ovaries is very low immediately after ovulation, but increases rapidly during the first 10 to 13 days thereafter. Early after ovulation, therefore, the gradient between local and systemic blood 
is still low, and metabolisation by the liver at this stage will have a relatively large impact on systemic progesterone. With increasing secretory capacity of the ovaries, the gradient between local and systemic concentration will increase. Systemic clearance may then have less impact on the contribution of systemic progesterone. Models that incorporate these dynamics have hardly been explored, and studies that assessed progesterone in the vena cava (Athorn et al., 2012, Virolainen et al., 2005) provide some insight in the dynamics of secretory capacity, but so far these studies are limited.

Another factor that has to be taken into account, is the dynamics in blood flow to the utero-ovarian complex. In sheep, the blood flow to the ovaries basically follows the rapid increase in luteal tissue mass in early pregnancy (Niswender et al., 2000), and because also the concentration of progesterone in utero-ovarian venous blood increases, the total input of progesterone to the circulation, as well as the local transfer to the uterus increases dramatically. These dynamics have to be taken into account when considering the above mentioned windows of nutritional effects on uterine progesterone supply.

\section{Conclusion}

It is clear that porcine corpora lutea develop to full functional size at around day 12 of pregnancy, independent of gonadotrophic input, and therefore nutritional manipulations before this stage are not controlled by LH. However, premating and post mating plane of nutrition, and possibly some dietary (fat or IGF-1 promoting) ingredients can influence luteal function early after ovulation through other mechanisms, which require more study. Even after luteal tissue becomes $\mathrm{LH}$ dependent, a prolonged (3-5 days) and severe suppression of $\mathrm{LH}$ is required to cause luteal failure and loss of pregnancy, and moderate feed restriction is not likely to have such an effect, although again data in this area is lacking. There are however, some indications that moderate feed restriction around the time of implantation may impede the second embryonic oestrogen signal for maternal recognition by modulation of the uterine environment, which may be an explanation for delayed type returns during seasonal infertility. More severe feed restriction such as total deprivation during high ambient temperatures or socially caused feed incidents, may have a profound effect on LH and pregnancy, but there are hardly any studies to support this.

The paradigm of high feed levels causing more embryo mortality may be true for the first few days after ovulation, but the existing evidence does not support the extrapolation of that paradigm later into the embryonic phase. The magnitude and pulsatile secretion of progesterone by the ovaries, as well as "shunting" of progesterone from the ovaries directly to the uterus has probably been overlooked. This may explain why a high plane of nutrition after the first week of pregnancy may actually increase progesterone secretion and supply to the uterus, and benefit embryo survival and maintenance of pregnancy, even though systemic progesterone may be reduced by a higher clearance rate. This hypothesis needs more investigation, taking into account the dynamics of progesterone secretion during early luteal tissue formation and the dynamics of blood flow to and from the utero-ovarian circulation.

\section{References}

Almeida FRCL, Mao J, Novak S, Cosgrove JR \& Foxcroft GR (2001) Effects of different patterns of feed restriction and insulin treatment during the luteal phase on reproductive, metabolic, and endocrine parameters in cyclic gilts. Journal of Animal Science 79 200-212. Anderson LL, Dyck GW, Mori H, Henricks DM \&
Melampy RM (1967) Ovarian function in pigs following hypophysial stalk transection or hypophysectomy. American Journal of Physiology 212 1188-1194.

Armstrong JD \& Britt JH (1987) Nutritionally-Induced Anestrus in Gilts: Metabolic and Endocrine Changes Associated with Cessation and Resumption of Estrous 
Cycles Journal of Animal Science 65 508-523.

Ashworth CJ, Beattie L \& Antipatis C (1999) Effects of preand post-mating nutritional status on hepatic function, progesterone concentration, uterine protein secretion and embryo survival in meishan pigs. Reproduction, Fertility and Development 11 67-73.

Athorn RZ, Stott P, Bouwman EG, Ashman R, O'Leary S, Nottle M \& Langendijk P (2011) Direct ovarian-uterine transfer of progesterone increases embryo survival in gilts. Reproduction, Fertility and Development 23, 921-928.

Athorn RZ, Stott P, Bouwman EG, Edwards AC, Blackberry MA, Martin GB \& Langendijk P (2012a) Feeding level and dietary energy source have no effect on embryo survival in gilts, despite changes in systemic progesterone levels. Animal Production Science 53 30-37.

Athorn RZ, Stott P, Bouwman,EG, Chen TY, Kennaway DJ \& Langendijk P (2012b) Effect of feeding level on luteal function and progesterone concentration in the vena cava during early pregnancy in gilts. Reproduction, Fertility and Development http://dx.doi. org/10.1071/RD11295

Barb CR, Kraeling RR, Rampacek GB \& Dove CR (1997) Metabolic changes during the transition from the fed to the acute feed-deprived state in prepuberal and mature gilts. Journal of Animal Science 75 781-789.

Barb CR, Barretta JB, Kraeling RR \& Rampacek GB (2001) Serum leptin concentrations, luteinizing hormone and growth hormone secretion during feed and metabolic fuel restriction in the prepuberal gilt. Domestic Animal Endocrinology 20 47-63

Booth PJ (1990) Metabolic influences on hypothalamicpituitary-ovarian function in the pig. In: Control of Pig Reproduction III. Eds Cole DJA, Foxcroft GR, Weir BJ. Journal of Reproduction and Fertility Supplements 40 89-100.

Booth PJ, Cosgrove JR \& Foxcroft GR (1996) Endocrine and metabolic responses to realimentation in feedrestricted prepubertal gilts: associations among gonadotropins, metabolic hormones, glucose, and utero ovarian development. Journal of Animal Science 74 840-848.

Brüssow KP, Schneider F, Wollenhaupt K \& Tuchscherer A (2011) Endocrine effects of GnRH agonist application to early pregnant gilts. Journal of Reproduction and development 57 242-248.

Chen TY, Stott P, Athorn RZ, Bouwman EG \& Langendijk P (2012a) Undernutrition during early follicle development has irreversible effects on ovulation rate and embryos. Reproduction, Fertility and Development 24 886-892.

Chen TY, Stott P, Bouwman EG \& Langendijk P (2012b) Effects of Pre-Weaning Energy Substitutions on PostWeaning Follicle Development, Steroid Hormones and Subsequent Litter Size in Primiparous Sows. Reproduction in Domestic Animals DOI: 10.1111/ rda. 12118

Dyck GW \& Strain JH (1983) Postmating feeding level effects on conception rate and embryonic survival in gilts. Canadian Journal of Animal Science 63 579-585.

Easton BG, Love RJ, Evans G \& Klupiec C (1993) A role for LH pulses in the establishment of pregnancy. In Manipulating Pig Production. (Ed. E. S. Batterham.). Australasian Pig Science Association, Canberra 1993 p. 246

Ferguson EM, Ashworth CJ, Edwards SA, Hawkins N, Hepburn N \& Hunter MG (2003) Effect of different nutritional regimens before ovulation on plasma concentrations of metabolic and reproductive hormones and oocyte maturation in gilts. Reproduction 126 61-71.

Fitz TA, Mayan MH, Sawyer HR \& Niswender GD (1982) Characterization of two steroidogenic cell types in the ovine corpus luteum. Biology of Reproduction 27 703-711.

Foxcroft GR (1997) Mechanisms mediating nutritional effects on embryonic survival in pigs. Journal of Reproduction and Fertility. Supplement 52, 47-61.

Gerritsen R, Soede NM, Langendijk P, Dieleman SJ, Hazeleger W, Laurenssen BFA \& Kemp B (2008) Feeding level does not affect progesterone levels in Intermittently Suckled sows with lactational ovulation. Animal Reproduction Science 103 379-384

Hoving LL, Soede NM, van der Peet-Schwering CM, Graat EA, Feitsma H \& Kemp B (2012) An increased feed intake during early pregnancy improves sow body weight recovery and increases litter size in young sows. Journal of Animal Science 89 3542-50.

Jindal R, Cosgrove JR, Aherne FX \& Foxcroft GR (1996) Effect of nutrition on embryonal mortality in gilts: association with progesterone. Journal of Animal Science 74 620-624.

Jindal R, Cosgrove JR \& Foxcroft GR (1997) Progesterone mediates nutritionally induced effects on embryonic survival in gilts. Journal of Animal Science $\mathbf{7 5}$ 1063-1070.

Krzymowski T, Kotwica J \& Stefanczyk-Krzymowska S (1990) Uterine and ovarian countercurrent pathways in the control of ovarian function in the pig. Journal of Reproduction and Fertility Supplement 40 179-191.

Langendijk P, Dieleman SJ, Gerritsen R, Hazeleger W, Mainsant M-L, Soede NM \& Kemp B (2007) Pulsatile release of luteinising hormone during the luteal phase in lactating and weaned sows. Reproduction, Fertility and Development 19 961-966.

Langendijk P, van den Brand H, Gerritsen R, Quesnel H, Soede NM \& Kemp B (2008). Porcine luteal function in relation to IGF-1 levels following ovulation during lactation or after weaning. Reproduction in Domestic Animals 43 131-136.

Magness RR, Reynolds LP \& Ford SP (1986) Evidence for uterine metabolism of progesterone during early pregnancy in the pig. Theriogenology 25 551-558.

Mao J, Zak LJ, Cosgrove JR, Shostak S \& Foxcroft GR (1999) Reproductive, metabolic, and endocrine responses to feed restriction and gnrh treatment in primiparous, lactating sows. Journal of Animal Science 77 724-735.

Mao J, Treacy BK, Almeida FRCL, Novak S, Dixon WT 
\& Foxcroft GR (2001) Feed Restriction and Insulin Treatment Affect Subsequent Luteal Function in the Immediate Postovulatory Period in Pigs: Progesterone Production In Vitro and Messenger Ribonucleic Acid Expression for Key Steroidogenic Enzymes. Biology of Reproduction 64 359-367.

Meduri G, Vu Hai MT, Jolivet A, Takemori S, Kominami S, Driancourt MA \& Milgrom E (1996) Comparison of cellular distribution of $\mathrm{LH}$ receptors and steroidogenic enzymes in the porcine ovary. Journal of Endocrinology 148 435-446.

Miller EA, Ge Z, Hedgpeth V \& Gadsby JE (2003) Steroidogenic responses of pig corpora lutea to insulinlike growth factor I (IGF-I) throughout the oestrous cycle. Reproduction 125 241-249.

Niswender GD, Schwall RH, Fitz TA, Farin CE \& Sawyer HR (1985) Regulation of luteal function in domestic ruminants: new concepts. Recent Progress in Hormone Research 41 101-151.

Niswender GD, Juengel JL, Silva PJ, Rollyson MK \& McIntush EW (2000) Mechanisms controlling the function and life span of the corpus luteum. Physiology Reviews 80 1-29.

Novak S, Treacy BK, Almeida FRCL, Mao J, Buhi WC, Dixon WT \& Foxcroft GR (2002) Regulation of IGF-I and porcine oviductal secretory protein (pOSP) secretion into the pig oviduct in the peri-ovulatory period, and effects of previous nutrition. Reproduction, Nutrition Development 42 355-372.

Novak S, Almeida FRCL, Cosgrove JR, Dixon WT \& Foxcroft GR. (2003) Effect of pre- and postmating nutritional manipulation on plasma progesterone,blastocyst development, and the oviductal environment during early pregnancy in gilts. Journal of Animal Science 81 772-783.

O'Leary S, Bouwman EG, Nottle MN \& Langendijk P (2011). Increasing endogenous progesterone in early pregnancy increases litter size in pigs. In: Manipulating pig production Ed. Van Barneveld RJ. Proceedings of the Australasian Pig Science Association, Adelaide, Nov 2011, pp 79.

Peltoniemi OAT, Easton BG, Love RJ, Klupiec C \& Evans G (1995) Effect of chronic treatment with a GnRH agonist (Goserelin) on LH secretion and early pregnancy in gilts. Animal Reproduction Science $\mathbf{4 0}$ 121-133.

Peltoniemi OAT, Love RJ, Klupiec C, Revell DK \& Evans G (1997a) Altered secretion of LH does not explain seasonal effects on early pregnancy in gilts. Animal Reproduction Science 49 215-224.

Peltoniemi OAT, Love RJ, Klupiec C \& Evans G (1997b) Effect of feed restriction and season on $\mathrm{LH}$ and prolactin secretion, adrenal response, insulin and FFA in group housed pregnant gilts. Animal Reproduction Science 49 179- 190.

Peltoniemi OA \& Virolainen JV (2006) Seasonality of reproduction in gilts and sows. Society for Reproduction and Fertility Supplements 62 205-18.

Pharazyn A, Foxcroft GR \& Aherne FX (1991) Temporal relationship between plasma progesterone concentrations in the utero-ovarian and jugular veins during early pregnancy in the pig. Animal Reproduction Science 26 323-332.

Prime GR \& Symonds HW (1993) Influence of plane of nutrition on portal blood flow and the metabolic clearance rate of progesterone in ovariectomised gilts. The Journal of Agricultural Science 121 389-397.

Prunier A, Martin C, Mounier AM \& Bonneau M (1993) Metabolic and endocrine changes associated with undernutrition in the peripubertal gilt. Journal of Animal Science 71 1887-1894.

Ptak A, Gregoraszczuk EL \& Rzasa J (2003) Growth hormone and insulin-like growth factor-I action on progesterone secretion by porcine corpora lutea isolated at various periods of the luteal phase. Acta Veterinaria Hungarica 51 197-208.

Ptak A, Kajta M \& Gregoraszczuk EL (2004) Effect of growth hormone and insulin-like growth factor-I on spontaneous apoptosis in cultured luteal cells collected from early, mature, and regressing porcine corpora lutea. Animal Reproduction Science $\mathbf{8 0}$ 267-279.

Quesnel H, Pasquier A, Mounier A-M \& Prunier A (2000) Feed restriction in cyclic gilts: Gonadotrophinindependent effects on follicular growth. Reproduction Nutrition Development 40 405-414

Quesnel H, Boulot S, Serriere S, Venturi E \& MartinatBotte F (2010) Post insemination level of feeding does not influence embryonic survival and growth in highly prolific pigs. Animal Reproduction Science $120120-124$.

Razdan P, Tummaruk P, Kindah H, Rodriguez-Martinez H, Hulten F \& Einarsson S (2004) The impact of induced stress during Days 13 and 14 of pregnancy on the composition of allantoic fluid and conceptus development in sows. Theriogenology 61 757-767

Schams D, Berisha B, Kosmann M, Einspanier R \& Amselgruber WM (1999) Possible role of growth hormone, IGFs, and IGF-binding proteins in the regulation of ovarian function in large farm animals. Domestic Animal Endocrinology 17 279-285.

Schams D \& Berisha B (2004) Regulation of corpus luteum function in cattle - an overview. Reproduction in Domestic Animals 39 241-251.

Soede NM, van der Lende T \& Hazeleger W (1999) Uterine luminal proteins and estrogens in gilts on a normal nutritional plane during the estrous cycle and on a normal or high nutritional plane during early pregnancy. Theriogenology 52 743-56.

Stefanczyk-Krzymowska S, Grzegorzewski W, Wasowska B, Skipor J \& Krzymowski T (1998) Local increase of ovarian steroid hormone concentration in blood supplying the oviduct and uterus during early pregnancy of sows. Theriogenology 50 1071-1080.

Toplis P, Ginesia MFJ \& Wrathall AE (1983) The influence of high food levels in early pregnancy on embryo survival in multiparous sows. Animal Production 37 45-48.

Tast A, Love RJ, Clarke IJ \& Evans G (2000) Effects of active and passive gonadotrophin-releasing hormone 
immunization on recognition and establishment of pregnancy in pigs. Reproduction Fertility Development 12 277-82.

Tast A, Peltoniemi O, Virolainen J \& Love, R (2002) Early disruption of pregnancy as a manifestation of seasonal infertility in pigs. Animal Reprodction Science 74 75-86.

Van den Brand H, Langendijk P, Soede NM \& Kemp B (2001) Effect of post-weaning dietary energy source on reproductive performance in primiparous sows. Journal of Animal Science 79 420-426.

Virolainen JV, Love RJ, Tast A \& Peltoniemi OA (2003) Effect of a gonadotrophin-releasing hormone antagonist on luteinising hormone secretion and early pregnancy in gilts. Reproduction Fertility Development 15 451-459.

Virolainen JV, Tast A, Sorsa A, Love RJ \& Peltoniemi OAT (2004) Changes in feeding level during early pregnancy affect fertility in gilts. Animal Reproduction Science 80 341-352.

Virolainen JV, Love RJ, Tast A \& Peltoniemi OA (2005a) Plasma progesterone concentration depends on sampling site in pigs. Animal Reproduction Science 86 305-316.
Virolainen JV, Peltoniemi OA, Munsterhjelm C, Tast A \& Einarsson S (2005b) Effect of feeding level on progesterone concentration in early pregnant multiparous sows. Animal Reproduction Science 90 $117-26$.

Webb R, Woad KJ \& Armstrong DG (2002) Corpus luteum (CL) function: local control mechanisms. Domestic Animal Endocrinology 23 277-285.

Wientjes JGM, Soede NM, van den Brand H \& Kemp B (2011) Nutritionally induced relationships between insulin levels during the weaning-to-ovulation interval and reproductive characteristics in multiparous sows: II. Luteal development, progesterone and conceptus development and uniformity. Reproduction in Domestic Animals 47 62-68.

Willis HJ, Zak LJ \& Foxcroft GR (2003) Duration of lactation, endocrine and metabolic state, and fertility of primiparous sows. Journal of Animal Science $\mathbf{8 1}$ 2088-2102.

Zak LJ, Williams IH, Foxcroft GR, Pluske JR, Cegielski AJ, Clowes EJ \& Aherne FX (1998) Feeding lactating primiparous sows to establish three divergent metabolic states: I. Associated endocrine changes and postweaning reproductive performance. Journal of Animal Science 76 1145-1153. 